\title{
PREMA MOGUĆNOSTIMA IMPLEMENTACIJE OBRAZOVANJA ZA ODRŽIVI RAZVOJ NA SVEUČILIŠTU
}

\author{
Ivanka Buzov, Elena Cvitković i Nena Rončević
}

\author{
Filozofski fakultet Sveučilišta u Splitu \\ Odsjek za sociologiju \\ Poljička cesta 35, 21000 Split \\ e-mail: ibuzov@ffst.hr
}

\begin{abstract}
Sažetak
U teorijskom se dijelu rada ukratko objašnjava koncept održivog razvoja, važnost obrazovanja za održivi razvoj kojim se može oživotvoriti održiva budućnost, odgovornost za sustavno promicanje i provedbu obrazovanja za održivi razvoj te potreba za implementacijom tema održivosti u studijske programe. U empirijskom dijelu rada izlažu se rezultati istraživanja provedenog 2016. na Sveučilištu u Rijeci (N=1347), koji su zatim uspoređeni s istraživanjem provedenim 2010. (N=1001). Polazeći od ispitivanja stavova studenata prema nekim dimenzijama obrazovanja za održivi razvoj, nadalje se analizira njihova zainteresiranost za različite teme održivog razvoja te za studijske programe fokusirane na ovaj koncept, zatim percepcija mogućnosti i načina implementacije problematike održivog razvoja u studijske programe, a u konačnici i percepcija odgovornosti za sustavno promicanje i provedbu obrazovanja za održivi razvoj. Usporedbom istraživanja iz 2010. i 2016. zaključuje se kako se navode slični kolegiji i teme kroz koje je obuhvaćen održivi razvoj te studenti iz uzorka 2016. pokazuju manju zainteresiranost za sve ponudene razine studija iz područja održivog razvoja. Nadalje, dio studenata ističe da ne raspolaže dovoljnim znanjem o održivom razvoju, a dio smatra da je teme održivosti potrebno implementirati u ranijim razinama obrazovanja. S obzirom na iskazani interes za teme o održivosti, najviše ističu potrebu za uključivanje u studijski program onih koje se odnose na ljudska prava, sigurnost hrane, siromaštvo i razvoj, ravnopravnost spolova te kvalitetu vode i zraka. Studenti pokazuju nerazumijevanje autonomnosti sveučilišta u kreiranju studijskih programa te odgovornost za promicanje i provedbu obrazovanja za održivi razvoj pripisuju Ministarstvu, Vladi i medijima.
\end{abstract}

Ključne riječi: odgoj i obrazovanje za održivi razvoj, odgovornost, područja održivosti, stavovi studenata

Personally, I can't find anything anywhere in higher education that doesn't in some way relate to sustainability.

(Shepard, 2015:83)

\section{UVOD}

Koncept održivog razvoja, iako prisutan već nekoliko desetljeća, sve se češće spominje u različitim područjima života, a složenost pojma nerijetko izaziva znanstvene i stručne prijepore. Značenje održivog razvoja ovisi o onima koji ga koriste, o polazištima koja 
imaju, u kojem kontekstu ga koriste, a možda značenje i razumijevanje održivog razvoja najviše ovisi o interesima i vrijednostima ljudi koji ga žele primijeniti (Rončević i Rafajac, 2012). Opće prihvaćena je i najcitiranija njegova postavka o međugeneracijskoj solidarnosti u korištenju postojećih prirodnih resursa za preživljavanje, a u svrhu ostvarenja pomirbe okolišnih, socijalnih i ekonomskih potreba, odnosno njihovo uravnoteženje, pa se može reći da ovaj razvojni koncept, predstavlja, za sada, najprihvatljiviji „orijentacijski okvir za međunarodnu politiku prema okolišu i razvojnu politiku“ (Cifrić, 2012:270) suvremenog svijeta.

U znanstvenoj i stručnoj literaturi prisutno je mnogo različitih definicija koncepta održivog razvoja, no najčešće je citirana definicija održivog razvoja ona koju je ponudila $\mathrm{Ko}$ misija Ujedinjenih naroda 1987. pod vodstvom bivše norveške premijerke Gro Harlem Brundtland: „Održivi razvoj jest razvoj koji izlazi u susret potrebama današnjih generacija pri čemu se vodi računa da zadovoljavanje potreba današnjih generacija ne dovede u pitanje mogućnost budućih generacija da zadovolje svoje potrebe“ (WCED, 1987:46). Sva nastojanja međunarodne politike u vezi sa zaštitom okoliša i njegovih resursa počivaju na ovoj definiciji. Nadalje, održivi se razvoj može definirati i kao sprječavanje narušavanja prosječnog životnog standarda za buduće generacije koji se ne može postići sve dok se siromaštvo izravno ne napadne, jer siromaštvo i degradacija okoliša idu jedno uz drugo (Goldstein, 2003, prema Drljača, 2012:5). Pojam „održivi razvoj“ može se također prevesti i kao uravnoteženi razvoj (Lay, 1994:289), a održivi razvoj sa sociologijskog, odnosno socio-antropološkog stanovišta Lay (1992:5), nadalje, definira kao „proces produkcije potreba i sredstava za njihovo zadovoljavanje kojima posljedica nije uništavanje i / ili smanjivanje kvalitete prirodnih resursa do granice ispod koje počinje ugrožavanje zdravlja, opstanka i obnavljanja živog svijeta“. Tako se on uzima i kao normativni koncept razvoju u kojem dominira ideja održivosti, a koji pronalazi balans između ekonomske učinkovitosti, socijalne kohezije i ekološke stabilnosti, no on ima i resursnu i moralnu perspektivu pa nije nužno antropocentrični koncept, već uključuje i ekocentrične pristupe (Cifrić, 2009:154-155).

U osnovi svih definicija prepoznaje se da je održivi razvoj koncept koji obuhvaća međusobno isprepletene ekonomsku, društvenu i ekološku dimenziju. Ove dimenzije ${ }^{1}$ se, od polaznih promišljanja o održivom razvoju i održivosti iz osamdesetih godina prošlog stoljeća, razrađuju kroz ključne dokumente svjetske razvojne politike, ${ }^{2}$ koje se stalno

1 Tri dimenzije održivog razvoja, okolišna, ekonomska i društvena, pratile su određenje i definiciju održivog razvoja od prvog Izvješća Brundtland komisije (WCED, 1987), a kasnije ja dodana kulturna (Kemp i Parto, 2005:14).

2 Kao sveobuhvatni planovi djelovanja u svakom području u kojem čovjek utječe na okoliš, globalno, nacionalno i lokalno, nakon Agende 21 (UNCED, 1992) s dodatkom Izvješća Rio+5, (Opća skupština UN-a, 1997) i Rio+10 (La Vina i sur. 2003) doneseni su i sljedeći planovi: Agenda 21 za kulturu (UCLG, 2002) s nastavkom opredijeljenosti za Agendu 21 na Konferenciji Ujedinjenih naroda o održivom razvoju 2012., s dokumentom pod naslovom Future we want (Opća skupština UN-a, 2012). Najnovija potvrda posvećenosti ciljevima Agende 21, kroz Agendu 2030. (Ciljevi održivog razvoja 2015.-2030.) iznijeta je i dokumentirana na Samitu Ujedinjenih naroda o održivom razvoju održanom 2015., u kojoj je razrađeno 17 ciljeva (Opća skupština $U N-a, 2015)$. 
nadopunjuju i kao razrađene danas predstavljaju novi konceptualni okvir temeljen na pet stupova održivosti: ekonomija (materijalno blagostanje kroz održivi rast), pravednost (društvena dobrobit kroz društvenu koheziju), ekologija (ekološka dobrobit kroz prirodno harmoniziranje), kultura (kulturno blagostanja kroz interkulturni dijalog) i sigurnost (mir i održiva stabilnost) (Červar i Bertoncelj, 2016). Nastojanja u svrhu osiguranja perspektive održivosti, odnosno podjednakog blagostanja za sve, s druge strane nužno pretpostavlja smanjenje potrošnje koja može biti u suprotnosti s materijalnim blagostanjem kako ga doživljava zapadna civilizacija, u smislu nužnog rezultata ekonomskog rasta. Međutim, uravnoteženo prožimanje ovih dimenzija pretpostavlja odustajanje od rasta, a blagostanje koje se priželjkuje je, u stvari, društveno (engl. well-being) što uvelike promiče „odrast “ kao polaznu točku „udaljavanja od imperativa rasta“ (Domazet i Dolenec, 2016:13).

Kako bi se u vremenu, koje je nazvano i „doba održivog razvoja“ (Sachs, 2015), ostvarila ova priželjkivana održiva budućnost, neophodno je osvještavanje putem obrazovanja za održivi razvoj (engl. education for sustainability / education for sustainable development), čija je provedba važna već na predškolskoj i osnovno školskoj te na srednjoškolskoj razini, kao i daljnja kontinuirana provedba tijekom procesa cjeloživotnog učenja. Drži se kako obrazovanje za održivi razvoj, ili održivost cilja da pomogne ljudima razumjeti međuovisnost života na Zemlji, efekte akcija i odluka koje se odnose na korištenje resursa i čimbenike koji podupiru ili sprječavaju održivi razvoj, a zaokupljeno je razvojem ljudske svijesti, vrijednosti i stavova, olakšavajući ljudima da budu djelotvorno involvirani u održivi razvoj (Palmer, 1998:30).

Primjena koncepta održivog razvoja u svakodnevni život dugotrajan je i složen proces. Pretpostavka tog procesa svakako je izazov i za modifikaciju, odnosno prilagodbu ili preciznije, transformaciju obrazovnog sustava smještenog u konkretan društveni kontekst (Sterling, 2004). Stoga je važno usredotočiti se i na sociološku dimenziju obrazovanja za održivi razvoj, odnosno naglasiti kako ono predstavlja proces učenja (novih) društvenih vrednota i to ne bilo kakvih, već vrednota koje teže održanju (ili povećanju) održivosti, održivih razvojnih horizonata, kao i proces učenja novih, fundamentalnih i općih te primijenjenih, znanja o održivosti kojima možemo razvijati ljudske sposobnosti, institucionalne i druge kapacitete kako bismo u sutrašnjici živjeli na više održiv način nego danas (Lay i Puđak, 2008:97).

Osim promjena na lokalnoj i globalnoj razini u ponašanju i načinu življenja djeluje se, prije svega, na promjenama koje im nužno prethode, a to su one na individualnoj razini. Današnji, a i budući naraštaji trebaju osim spremnosti da ulažu u učenje i znanje biti spremni na korjenito mijenjanje stava prema okolišu i društvu. $U$ tom smislu se $u$ najnovijim perspektivama o održivom razvoju, kako na europskoj tako i na globalnoj razini, posebice naglašava nužnost povezivanja dominantnih društvenih procesa na po-

3 Iako se u dijelu tumača ovog izraza, koji bi podjednako označavao „novu teoriju, pokret i vokabular“, pronalazi i potencijalna karakteristika „subverzivne utopije“ u smislu imperativa za promjenom svjetonazora koji podrazumijeva „zastrašujuća odricanja“ (Domazet i Dolenec, 2016), prije svega od materijalnog (više o tome u: D’Alisa i sur., 2016). 
četku 21. stoljeća što se naglašava i u ciljevima Agende za održivi razvoj 2030. (Opća skupština UN-a, 2015). ${ }^{4}$

Iako se stavovi prema okolišu počinju razvijati u vrlo ranoj životnoj dobi, posebnu odgovornost imaju institucije visokog obrazovanja za koje se, između ostalog, drži da bi također trebale imati moralnu odgovornost, ili socijalnu misiju u smislu i povećanja znanja o okolišu i razvijanja vrijednosti prema okolišu kod studenata (McMillan i sur., 2004:19). Sadašnji će studenti postati lideri budućih zajednica i oni koji skorim ulaskom u svijet rada postaju novi kreatori daljnje budućnosti (Rončević i sur., 2008:65), pa su kao takvi bili ciljana populacija i u brojnim ranijim istraživanjima o ekološkoj svijesti u Hrvatskoj tijekom posljednjih tridesetak godina.

Upravo zbog svega navedenog u ovom radu analiziraju se stavovi studenata Sveučilišta u Rijeci u vezi s obrazovanjem za održivi razvoj. Ispitani su stavovi studenata o načinima implementacije obrazovanja za održivi razvoj i preprekama koje stoje pred procesom implementacije. Osim toga, budući da obrazovanje za održivi razvoj zahtijeva uključenost društvenih struktura, ispitani su i stavovi studenata o odgovornosti za sustavno promicanje i provedbu obrazovanja za održivi razvoj u sveučilišne djelatnosti, a posebice o zainteresiranosti samih studenata za uključivanjem određenih tema i kolegija o održivosti u studijske programe.

\section{METODOLOGIJA ISTRAŽIVANJA}

\subsection{Ciljevi istraživanja, hipoteze i uzorak}

Opći je cilj istraživanja analizirati stavove studenata Sveučilišta u Rijeci i utvrditi postoje li razlike u njihovim stavovima prema obrazovanju za održivi razvoj s obzirom na rezultate istraživanja provedenih 2010. i 2016., odnosno istražiti je li došlo do promjene stavova u navedenom razdoblju.

U skladu s postavljenim istraživačkim problemom određeni su i specifični ciljevi istraživanja koji se prije svega odnose na ispitivanje percepcije mogućnosti implementacije obrazovanja za održivi razvoj u visokoškolske ustanove, analizu procjene o odgovornostima za njegovo promicanje i provedbu te zainteresiranost $u$ odnosu na preferencije prema uključivanju pojedinih tema održivosti u studijske programe te općenito zainteresiranost za stjecanje diplome u području održivosti.

Kao što je već spomenuto uspoređuju se rezultati dvaju uzastopnih istraživanja na nezavisnim uzorcima. Prvo istraživanje provedeno je u jesen akademske godine 2010. / 2011. (Rončević i Rafajac, 2012), a drugo u proljeće akademske godine 2015. / 2016. na usporedivom uzorku koristeći se istim postupkom prikupljanja i istim mjernim instrumentima. Populaciju ispitanika predstavljao je reprezentativan uzorak studenata Sveučilišta u Rijeci (Tablica 1). U istraživanju provedenom 2010. sudjelovalo je $\mathrm{N}=1001$, a onom provedenom 2016. $\mathrm{N}=1347$ studenata.

4 To se, između ostalog, odnosi na naglašavanje i uvođenje u ciljeve Agende 2030 aktualnog procesa migracija. Više o tome u: Fudge (2015), Hackl (2018). 
Tablica 1. Frekvencije i postoci fakultetâ i odjelâ Sveučilišta u Rijeci s obzirom na godinu istraživanja

\begin{tabular}{|c|c|c|c|c|}
\hline \multirow{2}{*}{\multicolumn{2}{|c|}{ Fakulteti i odjeli Sveučilišta u Rijeci }} & \multicolumn{2}{|c|}{ Godina istraživanja } & \multirow{3}{*}{$\begin{array}{c}\text { Ukupno } \\
111 \\
\end{array}$} \\
\hline & & \multirow{2}{*}{$\begin{array}{c}2016 . \\
52 \\
\end{array}$} & \multirow{2}{*}{$\begin{array}{c}2010 . \\
59\end{array}$} & \\
\hline \multirow{2}{*}{ 1. Akademija primijenjenih umjetnosti } & Frekvencija (f) & & & \\
\hline & $\%$ unutar godine & $5,20 \%$ & $4,40 \%$ & $4,70 \%$ \\
\hline \multirow{2}{*}{ 2. Ekonomski fakultet } & Frekvencija (f) & 153 & 78 & 231 \\
\hline & $\%$ unutar godine & $15,30 \%$ & $5,80 \%$ & $9,80 \%$ \\
\hline \multirow{2}{*}{$\begin{array}{l}\text { 3. Fakultet za menadžment u turizmu i } \\
\text { ugostiteljstvu }\end{array}$} & Frekvencija (f) & 0 & 161 & 161 \\
\hline & $\%$ unutar godine & $0,00 \%$ & $12,00 \%$ & $6,90 \%$ \\
\hline \multirow{2}{*}{ 4. Filozofski fakultet } & Frekvencija (f) & 81 & 96 & 177 \\
\hline & $\%$ unutar godine & $8,10 \%$ & $7,10 \%$ & $7,50 \%$ \\
\hline \multirow{2}{*}{ 5. Građevinski fakultet } & Frekvencija (f) & 107 & 109 & 216 \\
\hline & $\%$ unutar godine & $10,70 \%$ & $8,10 \%$ & $9,20 \%$ \\
\hline \multirow{2}{*}{ 6. Medicinski fakultet } & Frekvencija (f) & 131 & 132 & 263 \\
\hline & $\%$ unutar godine & $13,10 \%$ & $9,80 \%$ & $11,20 \%$ \\
\hline \multirow{2}{*}{ 7. Odjel za biotehnologiju } & Frekvencija (f) & 0 & 79 & 79 \\
\hline & $\%$ unutar godine & $0,00 \%$ & $5,90 \%$ & $3,40 \%$ \\
\hline \multirow{2}{*}{ 8. Odjel za fiziku } & Frekvencija (f) & 16 & 33 & 49 \\
\hline & $\%$ unutar godine & $1,60 \%$ & $2,40 \%$ & $2,10 \%$ \\
\hline \multirow{2}{*}{ 9. Odjel za informatiku } & Frekvencija (f) & 45 & 72 & 117 \\
\hline & $\%$ unutar godine & $4,50 \%$ & $5,30 \%$ & $5,00 \%$ \\
\hline \multirow{2}{*}{ 10. Odjel za matematiku } & Frekvencija (f) & 32 & 70 & 102 \\
\hline & $\%$ unutar godine & $3,20 \%$ & $5,20 \%$ & $4,30 \%$ \\
\hline \multirow{2}{*}{ 11. Pomorski fakultet } & Frekvencija (f) & 86 & 87 & 173 \\
\hline & $\%$ unutar godine & $8,60 \%$ & $6,50 \%$ & $7,40 \%$ \\
\hline \multirow{2}{*}{ 12. Tehnički fakultet } & Frekvencija (f) & 111 & 132 & 243 \\
\hline & $\%$ unutar godine & $11,10 \%$ & $9,80 \%$ & $10,30 \%$ \\
\hline \multirow{2}{*}{ 13. Učiteljski fakultet } & Frekvencija (f) & 65 & 61 & 126 \\
\hline & $\%$ unutar godine & $6,50 \%$ & $4,50 \%$ & $5,40 \%$ \\
\hline \multirow{2}{*}{ 14. Pravni fakultet } & Frekvencija (f) & 122 & 121 & 243 \\
\hline & $\%$ unutar godine & $12,20 \%$ & $9,00 \%$ & $10,30 \%$ \\
\hline \multirow{2}{*}{ 15. Zdravstveni studiji } & Frekvencija (f) & 0 & 57 & 57 \\
\hline & $\%$ unutar godine & $0,00 \%$ & $4,20 \%$ & $2,40 \%$ \\
\hline \multirow{2}{*}{ Ukupno } & Frekvencija (f) & 1001 & 1347 & 2348 \\
\hline & $\%$ unutar godine & $100,00 \%$ & $100,00 \%$ & $100,00 \%$ \\
\hline
\end{tabular}

\subsection{Metoda, instrument, postupak prikupljanja i obrade podataka}

U istraživanju je primijenjena korelacijska i deskriptivna metoda, podaci su prikupljeni postupkom anketiranja, a kao instrument korišten je anketni upitnik. Anketni upitnik sastojao se od preambule u kojoj su kratko objašnjeni svrha i ciljevi istraživanja te od 
triju poglavlja: (I) Opći podaci, (II) Održivi razvoj i (III) Obrazovanje za održivi razvoj. U općem dijelu traženi su podaci putem kojih se u obradi podataka ispitanike grupiralo u nezavisne skupine (spol, godina studija, uspjeh na kraju prošle školske godine, odnosno uspjeh na studiju, fakultet, kvaliteta življenja, stupanj obrazovanja majke i oca). Istraživanje je provedeno na isti način kao i 2010. Kontaktirani su dekani, odnosno prodekani za nastavu svih fakulteta i pročelnici odjela Sveučilišta u Rijeci, koji su podržali i pomogli provedbu istraživanja. ${ }^{6}$

Ispitanici su anketirani na nastavi, na početku ili na kraju sata, a samo popunjavanje upitnika trajalo je između 15 i 20 minuta.

Obrada podataka izvršena je putem Statističkog programa za društvene znanosti (IBM SPSS Statistics 24). U obradi podataka koristile su se metode univarijatne i bivarijatne statistike. Univarijatna statistika korišstena je kako bi se otkrili podaci iz 2016., a bivarijatna kako bi se usporedili rezultati uzastopnih istraživanja na nezavisnim uzorcima. Podaci dobiveni univarijatnom statistikom prikazani su kroz frekvencije, postotke te mjere centralne tendencije i varijabilnosti. Od postupaka bivarijatne statistike korišteni su t-test za utvrđivanje razlika između rezultata istraživanja dobivenih 2010. i 2016. godine te test hi-kvadrat za utvrđivanje povezanosti varijabli. Korišten je i Cramerov V koeficijent koji iskazuje stupanj povezanosti između dviju varijabli.

\section{REZULTATI ISTRAŽIVANJA I INTERPRETACIJA}

U prvom dijelu iznose se rezultati koji se odnose na pitanje jesu li studenti tijekom dotadašnjeg studiranja slušali o temama o održivom razvoju, kao i postoje li razlike $s$ obzirom na godinu istraživanja. Zatim su prikazani rezultati istraživanja iz 2016. na pitanju tema za koje su zainteresirani, kao i jesu li zainteresirani za određenu studijsku razinu iz područja održivog razvoja te je dana usporedba s istraživanjem iz 2010. Treći dio odnosi se na prikaz stavova prema implementaciji obrazovanja za održivi razvoj na sveučilišnoj razini, a zatim se ispituje procjena odgovornosti za sustavno promicanje i provedbu obrazovanja za održivi razvoj. Univarijatna statistika korištena je kako bi se prokazali podaci iz 2016., a bivarijatna kako bi se usporedili rezultati uzastopnih istraživanja na nezavisnim uzorcima.

\subsection{Jesu li studenti tijekom studija slušali kolegij(e) iz područja održivog razvoja?}

U Tablici 2 prikazana je raspodjela odgovora ispitanika 2010. i 2016., s obzirom na to jesu li studenti tijekom studija slušali neki kolegij u kojem se obrađivala problematika održivog razvoja.

\footnotetext{
5 Zahvaćene su prva godina preddiplomskog studija i zadnja godina diplomskog studija. Prva godina zato što se radi o studentima koji su tek počeli studirati, a zadnja godina jer je riječ o studentima koji su (većinom) pri kraju svog formalnog obrazovanja.

6 Ovom im prilikom im zahvaljujemo na podršci i suradnji.
} 
Tablica 2. Frekvencije (f) i postoci (\%) sobzirom na to jesu li studenti tijekom studija slušali neki kolegij u kojem su se obradivale teme održivog razvoja / održivosti - rezultati 2010. i 2016.

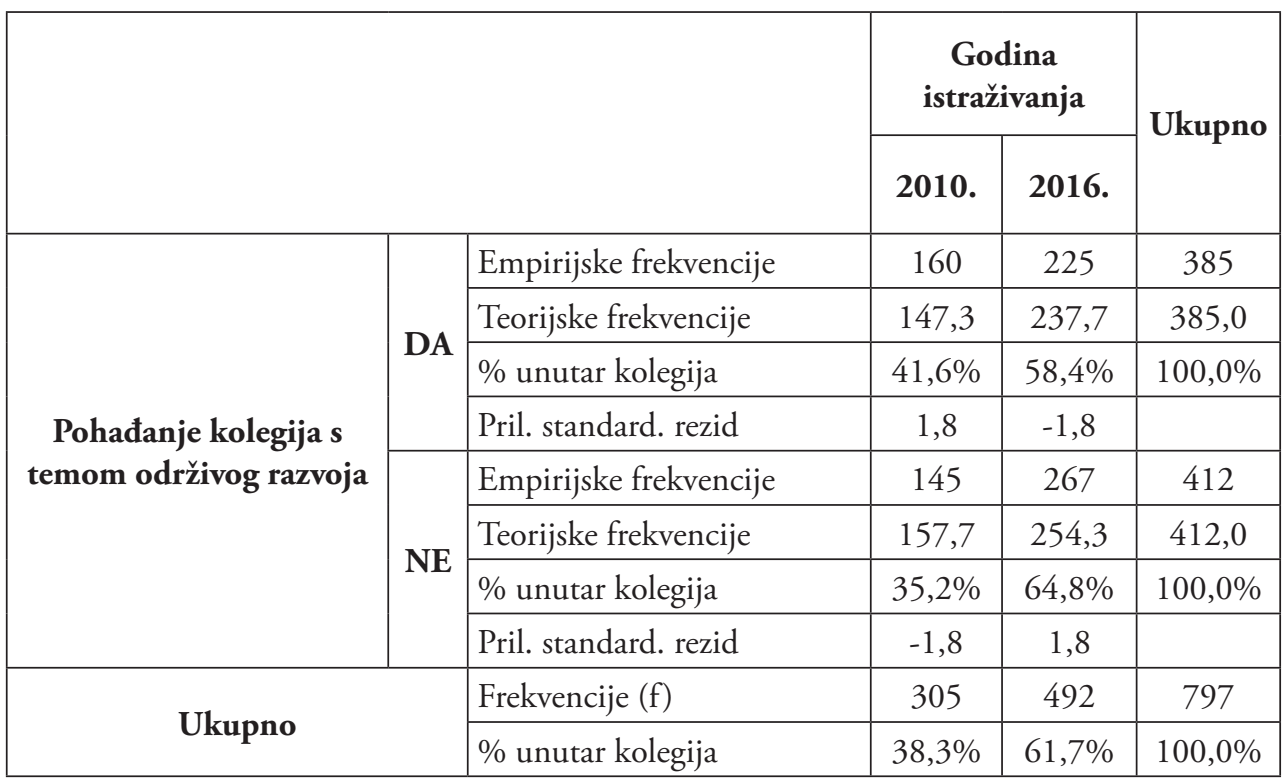

Proveden je test hi-kvadrat kako bi se utvrdilo postoji li statistički značajna povezanost varijable odslušan kolegij i varijable godina istraživanja (2010. i 2016.) te je utvrđeno da ne postoji statistički značajna povezanost između varijabli ${ }^{7}$ (Tablica 1 ), što drugim riječima sugerira zaključak da je zastupljenost kolegija u kojima se obrađuje problematika održivog razvoja na razini prethodnog mjerenja, odnosno kako nema značajnijih pomaka. Činjenica da u 2016. nalazimo čak 53,7\% studenata sudionika istraživanja koji izjavljuju da u okviru svog studija nisu slušali i obrađivali teme iz područja održivog razvoja. Stoga nas je zanimalo jesu li oni uopće zainteresirani za teme i studijske razine iz područja održivosti te imali promjena između uzastopnih istraživanja?

\section{2. (Ne)zainteresiranost za studiranjem područja održivog razvoja?}

Najprije su prikazani stavovi studenata iz istraživanja provedenog 2016. odnosno razina njihove zainteresiranosti za uključivanjem područja održivosti u studijske programe. Studentima su ponuđene 42 teme koje se mogu promatrati sa stajališta održivosti te su na temelju toga na ljestvici od 1 do 5 (uopće nisam zainteresiran/a do u potpunosti sam zainteresiran/a) iskazivali razinu zainteresiranosti za uvođenjem određene teme u studijski program koji pohađaju. Prvo su prikazani deskriptivni rezultati istraživanja iz 2016. (Tablica 3), a zatim je dana usporedba s rezultatima istraživanja iz 2010. (Tablica 4).

$7 \chi^{2}=3,412, d f=1, p>0,05, C V=0,065, p>0,05$ 
Tablica 3. Postoci (\%), aritmetičke sredine (M) i standardne devijacije (SD) varijabli u vezi s (ne)zainteresiranošću za uključivanjem navedenih područja održivosti u studijski program

\begin{tabular}{|c|c|c|c|c|c|c|c|}
\hline \multirow{2}{*}{ Područje održivosti } & \multicolumn{5}{|c|}{ Zainteresiranost studenata* } & \multirow{2}{*}{$\mathbf{M}$} & \multirow{2}{*}{ SD } \\
\hline & 1 & 2 & 3 & 4 & 5 & & \\
\hline Ljudska prava & 7,3 & 8,5 & 18,3 & 32,7 & 33,3 & 3,76 & 1,206 \\
\hline Sigurnost hrane & 7,5 & 8,2 & 18,7 & 33,4 & 32,2 & 3,75 & 1,204 \\
\hline Siromaštvo i razvoj & 8,4 & 8,3 & 20,5 & 32,8 & 29,9 & 3,68 & 1,221 \\
\hline Iskorjenjivanje siromaštva i gladi & 8,0 & 8,7 & 19,7 & 34,2 & 29,3 & 3,68 & 1,208 \\
\hline Djelovanje u kriznim situacijama & 6,2 & 8,4 & 21,4 & 39,1 & 24,9 & 3,68 & 1,123 \\
\hline Ravnopravnost spolova & 11,4 & 9,9 & 19,4 & 24,2 & 35,0 & 3,62 & 1,352 \\
\hline Kvaliteta vode i zraka & 7,5 & 10,1 & 24,8 & 31,7 & 26,0 & 3,59 & 1,189 \\
\hline Briga za psiho-fizičko zdravlje ljudi & 9,1 & 10,6 & 19,5 & 34,5 & 26,4 & 3,58 & 1,236 \\
\hline Tehnologije i održivi razvoj & 8,9 & 9,4 & 24,7 & 33,0 & 23,9 & 3,54 & 1,204 \\
\hline $\begin{array}{l}\text { Klimatske promjene i utjecaj na budućnost } \\
\text { društva }\end{array}$ & 8,8 & 9,8 & 23,8 & 35,0 & 22,6 & 3,53 & 1,194 \\
\hline Nutricionizam, zdravlje i okoliš & 9,5 & 12,5 & 21,4 & 30,2 & 26,6 & 3,52 & 1,264 \\
\hline $\begin{array}{l}\text { Obnovljivi izvori energije i energetska } \\
\text { učinkovitost }\end{array}$ & 7,4 & 11,5 & 26,2 & 31,1 & 23,8 & 3,52 & 1,185 \\
\hline Sigurnost okoliša & 9,0 & 10,2 & 25,4 & 30,7 & 24,8 & 3,52 & 1,220 \\
\hline Kulturna raznolikost & 10,4 & 12,6 & 23,0 & 33,7 & 20,3 & 3,41 & 1,234 \\
\hline Nove tehnologije održive gradnje & 10,5 & 13,6 & 28,7 & 29,5 & 17,8 & 3,31 & 1,212 \\
\hline Održivi turizam & 12,4 & 14,0 & 25,3 & 28,1 & 20,2 & 3,30 & 1,280 \\
\hline Organska proizvodnja hrane & 12,8 & 16,3 & 25,4 & 24,6 & 20,8 & 3,24 & 1,303 \\
\hline Biznis, održivost i korporativna odgovornost & 12,3 & 15,3 & 25,0 & 31,2 & 16,1 & 3,23 & 1,245 \\
\hline Održiva infrastruktura (voda, otpad, energija) & 10,5 & 15,4 & 32,1 & 26,8 & 15,1 & 3,21 & 1,186 \\
\hline Održivi gradovi & 11,2 & 15,3 & 30,4 & 27,6 & 15,6 & 3,21 & 1,207 \\
\hline Ekotoksiologija, onečišćenje i zdravlje okoliša & 11,6 & 16,1 & 29,6 & 27,8 & 14,9 & 3,18 & 1,210 \\
\hline Ekološki (zeleni) dizajn i građenje & 13,4 & 18,6 & 25,0 & 25,8 & 17,3 & 3,15 & 1,285 \\
\hline Obrazovanje za kulturu mira & 12,7 & 17,7 & 28,2 & 25,3 & 16,0 & 3,14 & 1,250 \\
\hline Održivi razvoj lokalne zajednice & 11,9 & 16,2 & 32,9 & 25,2 & 13,8 & 3,13 & 1,194 \\
\hline Ekološka pravednost & 11,3 & 19,3 & 32,8 & 25,8 & 10,7 & 3,05 & 1,154 \\
\hline Održivo upravljanje obalnim pojasom & 14,8 & 18,1 & 29,7 & 21,9 & 15,4 & 3,05 & 1,268 \\
\hline $\begin{array}{l}\text { Globalizacija i internacionalna trgovina / } \\
\text { razmjena }\end{array}$ & 14,1 & 16,8 & 31,7 & 25,8 & 11,6 & 3,04 & 1,205 \\
\hline Globalno upravljanje i održivost & 14,2 & 18,4 & 30,8 & 25,6 & 11,0 & 3,01 & 1,203 \\
\hline
\end{tabular}


Soc. ekol. Zagreb, Vol. 29 (2020.), No. 1

Ivanka Buzov i sur.: Prema mogućnostima implementacije obrazovanja za održivi razvoj na sveučilištu

\begin{tabular}{|l|c|c|c|c|c|c|c|}
\hline Pravo okoliša & 14,0 & 19,4 & 32,2 & 21,2 & 13,3 & 3,00 & 1,225 \\
\hline $\begin{array}{l}\text { Održivo upravljanje / gospodarenje } \\
\text { poljoprivrednim tlom, zaštita tla }\end{array}$ & 14,3 & 20,8 & 31,8 & 20,4 & 12,8 & 2,97 & 1,223 \\
\hline Ekonomika okoliša & 13,7 & 21,3 & 31,0 & 22,9 & 11,1 & 2,97 & 1,198 \\
\hline Arhitektura i održivi razvoj & 13,8 & 20,6 & 28,6 & 29,3 & 7,7 & 2,96 & 1,165 \\
\hline Bioraznolikost, okolišni sustavi i konzervacija & 15,5 & 21,6 & 26,7 & 25,8 & 10,3 & 2,94 & 1,227 \\
\hline Okoliš i internacionalni razvoj & 13,3 & 20,5 & 35,6 & 21,3 & 9,3 & 2,93 & 1,148 \\
\hline Održivi transport & 15,0 & 21,1 & 32,8 & 20,1 & 11,1 & 2,91 & 1,203 \\
\hline Ekoinženjerstvo & 15,8 & 23,8 & 29,3 & 22,0 & 9,2 & 2,85 & 1,197 \\
\hline Aktivno građanstvo & 16,4 & 20,7 & 31,6 & 25,4 & 5,9 & 2,84 & 1,152 \\
\hline Politika okoliša & 16,7 & 21,6 & 33,6 & 18,5 & 9,5 & 2,82 & 1,191 \\
\hline Pomorstvo i promet u funkciji održivog razvoja & 18,7 & 24,0 & 30,7 & 16,9 & 9,7 & 2,75 & 1,218 \\
\hline Bioekonomija, biomaterijali, biorafiniranje & 21,4 & 23,6 & 24,9 & 22,3 & 7,9 & 2,72 & 1,245 \\
\hline Bioetika & 21,0 & 24,4 & 25,3 & 21,1 & 8,2 & 2,71 & 1,241 \\
\hline
\end{tabular}

* Skala procjene zainteresiranosti: 1 - uopće nisam zainteresiran/a, 2 - nezainteresiran/a, 3 - niti zainteresiran/a niti nezainteresirana, 4 - zainteresiran/a, 5 - u potpunosti zainteresiran/a

Prema rezultatima prikazanim u Tablici 2 studenti su 2016. najviše iskazivali interes (zainteresiran $+\mathrm{u}$ potpunosti zainteresiran) za uključivanjem sljedećih područja održivosti u studijski program: ljudska prava (66\%), sigurnost hrane (65,6\%), siromaštvo i razvoj $(62,7 \%)$, iskorjenjivanje siromaštva i gladi $(63,5 \%)$, djelovanje u kriznim situacijama (64\%), ravnopravnost spolova $(59,2 \%)$, kvaliteta vode i zraka $(57,7 \%)$, briga za psiho-fizičko zdravlje ljudi (60,9\%), tehnologije i održivi razvoj (56,9\%), klimatske promjene i utjecaj na budućnost društva $(57,6 \%)$, nutricionizam, zdravlje i okoliš $(56,8 \%)$, obnovljivi izvori energije i energetska učinkovitost $(54,9 \%)$ te sigurnost okoliša $(55,5 \%)$. Najmanji interes studenata iskazan je za: održivi transport $(31,2 \%)$, ekoinženjerstvo $(31,2 \%)$, aktivno građanstvo $(31,3 \%)$, politiku okoliša $(28 \%)$, pomorstvo i promet u funkciji održivog razvoja $(26,6 \%)$, bioekonomiju, biomaterijale, biorafiniranje $(30,2 \%)$ te bioetiku $(30,3 \%)$, što se logično nastavlja na već uočeni nedostatak sadržaja u studijskim programima o složenom korpusu tema i pitanja koja se jasno ili implicitno odnose na perspektivu održivog razvoja, a projiciraju se kroz globalne ciljeve održivog razvoja. ${ }^{8}$

8 Studentima je postavljeno i otvoreno pitanje u kojem su mogli navesti interes za neku drugu temu, odnosno područje. Kao odgovore, navodili su: fizika i održivi razvoj, genetski modificirana hrana, gospodarenje otpadom, kulturologija, informatička tehnologija, očuvanje kulturne baštine na našim područjima, održivo prostorno planiranje, održivost zdravog razuma u Vladi Republike Hrvatske, onečišćenje koje uzrokuju tvornice, politika, ponovno korištenje smeća, pravo struke, prednosti veganskog načina života za bolju budućnost, primjena matematike u održivom razvoju, ravnopravnost spolnih orijentacija, razvoj efikasnosti obnovljivih izvora energije i masovnog transporta, solarna energija, energija vjetra, umanjivanje monopola farmaceutske industrije, zbrinjavanje medicinskog otpada, utjecaj ljudi na okoliš. 
S ciljem utvrđivanja postoji li statistički značajna razlika između dobivenih rezultata istraživanja iz 2016. i onih iz 2010. proveden je t-test za nezavisne uzorke na pitanju zainteresiranosti studenata prema temama o održivosti (Tablica 4).

Tablica 4. Rezultati 2010. godine u odnosu na 2016. na pitanju zainteresiranosti za uključivanjem navedenih područja održivosti u studijski program

\begin{tabular}{|c|c|c|c|c|c|c|c|}
\hline Područje održivosti & Godina & $\mathbf{M}$ & SD & $\mathbf{t}$ & df & $\mathbf{p}$ & $\begin{array}{c}\text { Razlika } \\
\text { među } \\
\text { godinama }\end{array}$ \\
\hline \multirow{2}{*}{$\begin{array}{l}\text { Bioraznolikost, okolišni sustavi } \\
\text { i konzervacija }\end{array}$} & 2010. & 2,82 & 1,158 & \multirow{2}{*}{$-2,413$} & \multirow{2}{*}{2321} & \multirow{2}{*}{0,016} & \multirow{2}{*}{$2010 .<2016$. } \\
\hline & 2016. & 2,94 & 1,227 & & & & \\
\hline \multirow{2}{*}{ Ljudska prava } & 2010. & 3,86 & 1,130 & \multirow{2}{*}{2,008} & \multirow{2}{*}{2220} & \multirow{2}{*}{0,045} & \multirow{2}{*}{$2010 .>2016$. } \\
\hline & 2016. & 3,76 & 1,206 & & & & \\
\hline \multirow{2}{*}{ Nutricionizam, zdravlje i okoliš } & 2010. & 3,40 & 1,200 & \multirow{2}{*}{$-2,408$} & \multirow{2}{*}{2205} & \multirow{2}{*}{0,016} & \multirow{2}{*}{$2010 .<2016$} \\
\hline & 2016. & 3,52 & 1,264 & & & & \\
\hline \multirow{2}{*}{$\begin{array}{l}\text { Obnovljivi izvori energije i } \\
\text { energetska učinkovitost }\end{array}$} & 2010. & 3,43 & 1,197 & \multirow{2}{*}{$-1,957$} & \multirow{2}{*}{2324} & \multirow{2}{*}{0,050} & \multirow{2}{*}{$2010 .<2016$. } \\
\hline & 2016. & 3,52 & 1,185 & & & & \\
\hline \multirow{2}{*}{ Održivi razvoj lokalne zajednice } & 2010. & 3,03 & 1,090 & \multirow{2}{*}{$-2,004$} & \multirow{2}{*}{2243} & \multirow{2}{*}{0,045} & \multirow{2}{*}{$2010 .<2016$. } \\
\hline & 2016. & 3,13 & 1,194 & & & & \\
\hline \multirow{2}{*}{$\begin{array}{l}\text { Održivo upravljanje / } \\
\text { gospodarenje (poljoprivrednim) } \\
\text { tlom, zaštita tla }\end{array}$} & 2010. & 2,86 & 1,133 & \multirow{2}{*}{$-2,238$} & \multirow{2}{*}{2328} & \multirow{2}{*}{0,025} & \multirow{2}{*}{$2010 .<2016$} \\
\hline & 2016. & 2,97 & 1,223 & & & & \\
\hline \multirow{2}{*}{ Organska proizvodnja hrane } & 2010. & 3,07 & 1,229 & \multirow{2}{*}{$-3,387$} & \multirow{2}{*}{2212} & \multirow{2}{*}{0,001} & \multirow{2}{*}{$2010 .<2016$. } \\
\hline & 2016. & 3,24 & 1,303 & & & & \\
\hline
\end{tabular}

Utvrđeno je da od 41 teme statistički značajna razlika postoji u samo sedam, pritom je manja zainteresiranost za jednu temu, a za preostalih šest iskazan je veći interes u 2016. u odnosu na 2010. Odnosno, veća je zainteresiranost za teme: bioraznolikost, okolišni sustavi i konzervacija; nutricionizam, zdravlje i okolis; održivi razvoj i lokalne zajednice; održivo upravljanje / gospodarenje (poljoprivrednim) tlom, zaštita tla; organska proizvodnja hrane te obnovljivi izvori energije i energetska učinkovitost, dok su za temu ljudska prava studenti 2010. iskazali veću zainteresiranost od studenata iz istraživanja provedenog 2016. No, ipak s obzirom da na zainteresiranosti za preostalih 35 tema nije utvrđena statistički značajna razlika, već da je ona na razini iz 2010., može se govoriti o stabilnoj i relativno visokoj zainteresiranosti za problematiku održivog razvoja.

Sljedeći rezultati odnose se na pitanje u kojoj su mjeri studenti zainteresirani studirati na različitim razinama studija, ukoliko bi takvi studiji bili ponuđeni iz područja održivog razvoja (preddiplomski studij, diplomski studij, stručni studij, doktorski studij). Studenti su procjenjivali na ljestvici od 1 do 5 (uopće nisam zainteresiran/a do u potpunosti zainteresiran/a). Nakon rezultata na deskriptivnoj razini koji se odnose na istraživanje iz 2016. (Tablica 5), analiziraju se razlike u odnosu na rezultate iz 2010. (Tablica 6). 
Tablica 5. Postoci (\%), aritmetičke sredine (M) i standardne devijacije (SD) varijabli pri procjeni zainteresiranosti studenata Sveučilišta u Rijeci za navedene razine studija iz područja održivog razvoja u 2016.

\begin{tabular}{|l|c|c|c|c|c|c|c|}
\hline \multirow{2}{*}{\multicolumn{1}{|c|}{ Razina studija }} & \multicolumn{5}{|c|}{ Zainteresiranost studenata* } & \multirow{2}{*}{ M } & \multirow{2}{*}{ SD } \\
\cline { 2 - 7 } & $\mathbf{1}$ & $\mathbf{2}$ & $\mathbf{3}$ & $\mathbf{4}$ & $\mathbf{5}$ & & \\
\hline Preddiplomski studij & 17,8 & 14,3 & 25,7 & 25,7 & 16,5 & 3,09 & 1,329 \\
\hline Diplomski studij & 17,5 & 14,3 & 27,1 & 26,2 & 14,9 & 3,07 & 1,303 \\
\hline Stručni studij & 23,2 & 17,9 & 31,5 & 20,2 & 7,2 & 2,70 & 1,229 \\
\hline Doktorski studij & 26,9 & 17,8 & 28,0 & 17,0 & 10,4 & 2,66 & 1,314 \\
\hline
\end{tabular}

* Skala procjene zainteresiranosti: 1 - uopće nisam zainteresiran/a, 2 - nezainteresiran/a, 3 - niti zainteresiran/a niti nezainteresirana, 4 - zainteresiran/a, 5 - u potpunosti zainteresiran/a

Kao što je vidljivo iz Tablice 5 u potpunosti zainteresiranih studenata za navedene razine studija iz područja održivog razvoja je između 7,2\% i 16,5\%, pri čemu se najviši postotak odnosi na preddiplomski studij (16,5\%), a najmanji postotak odnosi se na stručni studij (7,2\%). Postotak zainteresiranih i u potpunosti zainteresiranih studenata je između 27,4\% i $49 \%$. Za razinu diplomskog studija zainteresirano je $41 \%$, a za stjecanje stupnja doktora znanosti u području održivosti zainteresirano je $27 \%$ studenata. Postotak studenata koji nisu zainteresirani za stjecanje stupnja obrazovanja u području održivosti kreće se između $41 \%$ i $45 \%$, dok se postotak neopredijeljenih kreće između 25\% i 32\%.

Primjenom t-test za nezavisne uzorke utvrđeno je da studenti iz uzorka u 2016. pokazuju manju zainteresiranost od studenata 2010. za sve razine studija, pa se može zaključiti da očito još uvijek nije došlo do dovoljne promjene vrijednosnih orijentacija i interesa. Poznavanje samih činjenica ne mora nužno utjecati na oblikovanje stavova i sustava vrijednosti koji će rezultirati odgovarajućim ponašanjem i donošenjem odluka (Devernay i sur., 2001), već se radi o sveobuhvatnom pristupu koji, prije svega, podrazumijeva poznavanje povezanosti između okoliša, društva i gospodarstva, što će podjednako dovesti do okolišno prihvatljivog i učinkovitog razvoja s perspektivom ostvarivanja društvene pravednosti.

Tablica 6. Rezultati 2010. u odnosu na 2016. u procjeni zainteresiranosti studenata Sveučilišta u Rijeci za navedene razine studija iz područja održivog razvoja

\begin{tabular}{|c|c|c|c|c|c|c|c|}
\hline Razina studija & Godina & $\mathbf{M}$ & SD & $\mathbf{t}$ & df & $\mathbf{p}$ & $\begin{array}{c}\text { Razlika među } \\
\text { godinama }\end{array}$ \\
\hline \multirow{2}{*}{ Preddiplomski studij } & 2010. & 3,29 & 1,244 & \multirow{2}{*}{3,685} & \multirow{2}{*}{2132} & \multirow{2}{*}{0,000} & \multirow{2}{*}{$2010 .>2016$} \\
\hline & 2016. & 3,09 & 1,329 & & & & \\
\hline \multirow{2}{*}{ Diplomski studij } & 2010. & 3,25 & 1,234 & \multirow{2}{*}{3,439} & \multirow{2}{*}{2215} & \multirow{2}{*}{0,001} & \multirow{2}{*}{$2010 .>2016$} \\
\hline & 2016. & 3,07 & 1,303 & & & & \\
\hline \multirow{2}{*}{ Stručni studij } & 2010. & 2,83 & 1,190 & \multirow{2}{*}{2,529} & \multirow{2}{*}{2002} & \multirow{2}{*}{0,012} & \multirow{2}{*}{ 2010.>2016. } \\
\hline & 2016. & 2,70 & 1,229 & & & & \\
\hline \multirow{2}{*}{ Doktorski studij } & 2010. & 2,97 & 1,326 & \multirow{2}{*}{5,412} & \multirow{2}{*}{1958} & \multirow{2}{*}{0,000} & \multirow{2}{*}{$2010 .>2016$} \\
\hline & 2016. & 2,66 & 1,314 & & & & \\
\hline
\end{tabular}




\subsection{Mogućnosti implementacije obrazovanja za održivi razvoj u sustav visokog obrazovanja}

U vezi s mogućnostima implementacije obrazovanja za održivi razvoj analiziraju se rezultati koji se odnose na procjenu stavova studenata o načinima implementacije ovog koncepta obrazovanja u sustav visokog obrazovanja, kao i na percepciju prepreka koje su postavljene pred njegovu implementaciju. Studenti su na ukupno deset tvrdnji na ljestvici od 1 do 5 iskazivali svoje slaganje ili neslaganje s navedenim tvrdnjama (1 u potpunosti se ne slažem do 5 u potpunosti se slažem).

Što se tiče rezultata istraživanja dobivenih obradom podataka na deskriptivnoj razini, na istraživanju provedenom 2016. (Tablica 7), prema distribuciji odgovora studenata, tvrdnje koje imaju najvišu vrijednost odnose se na stav kako bi svi sveučilišni nastavnici u izvedbi programa trebali uključiti znanja, vrijednosti i vještine za održivo življenje u zajednici te stav kako su teme održivog razvoja važne za njihovu struku i buduće zanimanje te bi im znanja o tome tijekom studiranja bila korisna. Ovo je izuzetno snažan i pozitivan nalaz imajući u obzir da je riječ o studentima koji studiraju u različitim područjima znanosti. Također, ovdje se prepoznaje i potreba osnaživanja nastavnika kako bi podnijeli dio odgovornosti i svoju nastavnu aktivnost u jednom dijelu orijentirali na interdisciplinaran i integralan pristup.

Ipak, čak 51\% studenta u 2016. smatra kako su kurikulumi na visokoškolskim ustanovama preopterećeni stručnim sadržajima, odnosno da nema prostora za dodatne sadržaje iz područja održivog razvoja. Dodatno, gotovo polovica $(48,9 \%)$ studenata ističe kako je potrebno osnovati posebnu obrazovnu ustanovu u kojoj bi se obrazovali stručnjaci i edukatori za održivi razvoj te $42 \%$ studenata smatra kako je obrazovanje za održivi razvoj moguće implementirati samo u nekim disciplinama, ne u svima pa je na tom tragu i rezultat kako $42,2 \%$ smatra da u svakom studiju treba biti osmišljen zaseban kolegij posvećen sadržajima održivog razvoja.

Svi ovi rezultati govore u prilog tome kako gotovo svaki drugi student smatra da je održivi razvoj samo još jedan dodatan sadržaj koji bi trebali savladati, a ne prepoznaje se koncept održivog razvoja kao integralan dio svakodnevne ljudske djelatnosti, tj. da se o njemu predaje kroskurikularno. Iz navedenog, može se zaključiti da studenti još uvijek ne opažaju da obrazovne institucije igraju važnu ulogu u procesu izgradnje znanja, vještina, svijesti, vrijednosti i održive akcije, potrebne za postizanje cilja održive budućnosti. Razvoj obrazovnih institucija i obrazovnog procesa nije moguć bez promjene obrazovanja, promjena odnosa prema okolišu, održivom ponašanju, a također nije moguć ako se trenutačno ponašanje ne mijenja kroz sustavno obrazovanje (Huckle, 2006, prema Anđić i Tatalović Vorkapić, 2017).

Oko tvrdnje da u kolegijima koje studenti slušaju, ili su slušali, nije moguće obrađivati teme održivog razvoja zbog specifičnosti discipline, podijeljena su mišljenja. $S$ navedenom se tvrdnjom ne slaže $37,3 \%$ studenata, slaže se njih $35 \%$, dok $27,6 \%$ studenata nije sigurno. Nadalje, 39,4\% studenata nije sigurno može li se nastavnike, zbog preopterećenosti obvezama, motivirati na integraciju obrazovanja za održivi razvoj. Ono što se svakako može istaknuti kao pozitivno jest da gotovo polovica studenata $(46,1 \%)$ smatra 


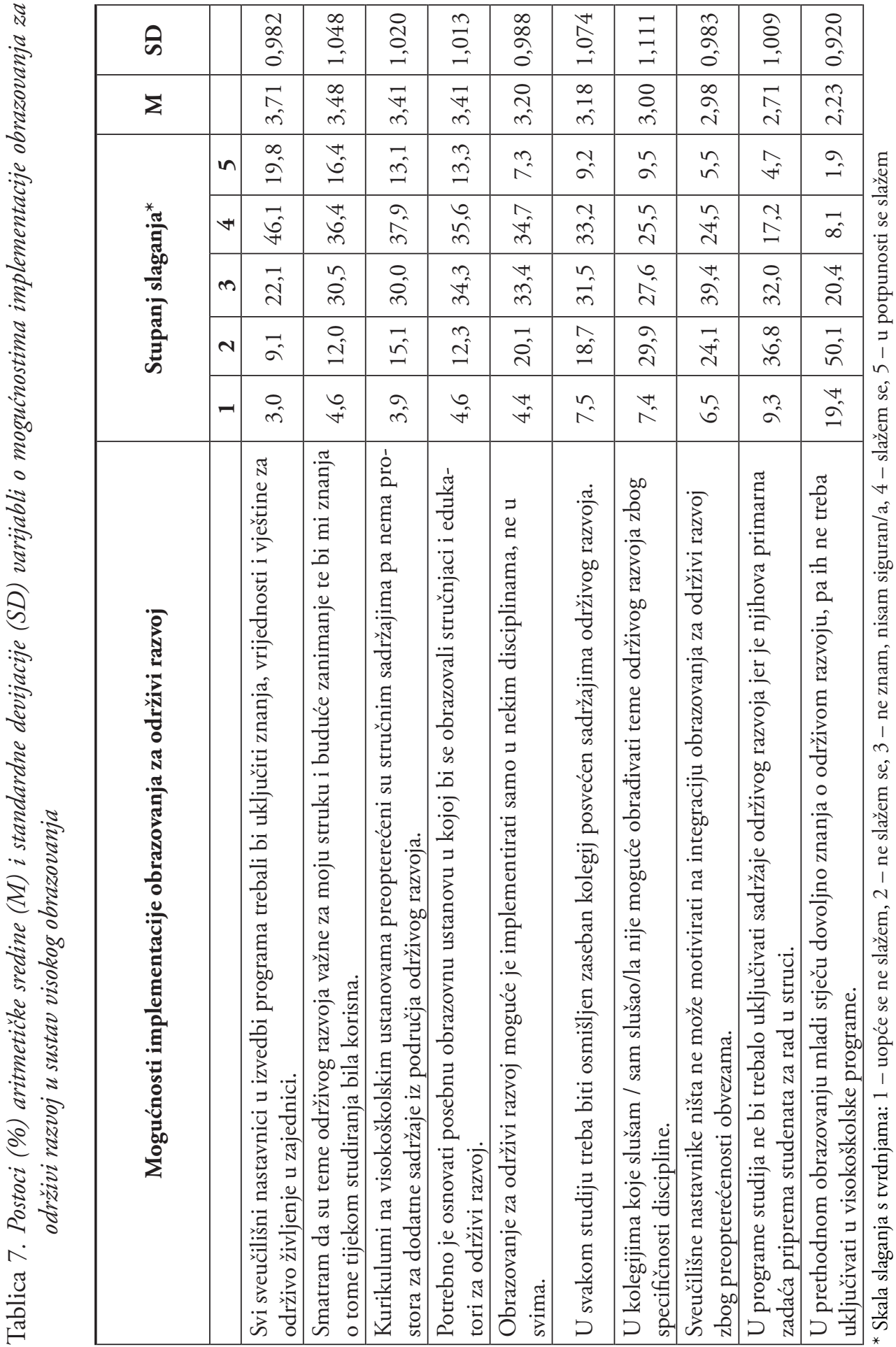


kako bi u programe studija trebalo uključivati sadržaje održivog razvoja bez obzira što je njihova primarna zadaća priprema studenata za rad u struci.

Kontekstualizirajući ove nalaze unutar aktualne rasprave o suvremenom kurikulumu i reforme osnovnoškolskog i srednjoškolskog obrazovanja kroz Školu za život, a s obzirom da obrazovanje za održivi razvoj predstavlja pothvat kojim se mlađe generacije pripremaju za izazove koji ih čekaju u budućnosti (Rakić i Vukušić, 2010), pozitivno je što studenti smatraju teme održivosti važnima za njihovu struku i buduće zanimanje te ističu potrebnim i njegovu integraciju u programe studija. Gotovo $70 \%$ studenata procjenjuje da u prethodnim, nižim, razinama obrazovanja mladi ne stječu dovoljno znanja o održivom razvoju, stoga se zaključuje o potrebi za uključivanjem sadržaja održivog razvoja u visokoškolske programe. $S$ obzirom da se u Hrvatskoj obrazovanje za održivi razvoj ne provodi na sustavan način, već ovisi o motivaciji i osposobljenosti nastavnika da ga integrira u aktualne nastavne programe te njegovoj sposobnosti da uskladi profesionalna djelovanja s promjenama i zahtjevima suvremenog društva (Kostović-Vranješ, 2016), pred sveučilišnim nastavnicima stoje novi zahtjevi i izazovi.

Tablica 8. Rezultati 2010. u odnosu na 2016. o mogućnostima implementacije obrazovanja za održivi razvoj

\begin{tabular}{|c|c|c|c|c|c|c|c|}
\hline $\begin{array}{l}\text { Mogućnosti implementacije } \\
\text { obrazovanja za održivi razvoj }\end{array}$ & Godina & $\mathbf{M}$ & SD & $\mathbf{t}$ & df & $\mathbf{p}$ & $\begin{array}{c}\text { Razlika među } \\
\text { godinama }\end{array}$ \\
\hline $\begin{array}{l}\text { Svi sveučilišni nastavnici bi } \\
\text { u izvedbi programa trebali }\end{array}$ & 2010. & 3,87 & 0,815 & \multirow{3}{*}{4,301} & \multirow{3}{*}{2314} & \multirow{3}{*}{0,000} & \multirow{3}{*}{$2010 .>2016$} \\
\hline uključiti znanja, vrijednosti i & & & & & & & \\
\hline $\begin{array}{l}\text { vještine za održivo življenje u } \\
\text { zajednici. }\end{array}$ & 2016. & 3,71 & 0,982 & & & & \\
\hline \multirow{2}{*}{$\begin{array}{l}\text { U kolegijima koje slušam / } \\
\text { sam slušao/la nije moguće } \\
\text { obrađivati teme održivog } \\
\text { razvoja zbog specifičnosti } \\
\text { discipline. }\end{array}$} & 2010 & 3,09 & 0,976 & \multirow[b]{2}{*}{2,053} & \multirow[b]{2}{*}{2269} & \multirow[b]{2}{*}{0,040} & \multirow[b]{2}{*}{$2010 .>2016$. } \\
\hline & 2016. & 3,00 & 1,111 & & & & \\
\hline \multirow{2}{*}{$\begin{array}{l}\text { Potrebno je osnovati posebnu } \\
\text { obrazovnu ustanovu u kojoj } \\
\text { bi se obrazovali stručnjaci i } \\
\text { edukatori za održivi razvoj. }\end{array}$} & 2010 & 3,53 & 0,916 & \multirow[b]{2}{*}{2,942} & \multirow[b]{2}{*}{2249} & \multirow[b]{2}{*}{0,003} & \multirow[b]{2}{*}{$2010 .>2016$} \\
\hline & 2016. & 3,41 & 1,013 & & & & \\
\hline
\end{tabular}

Što se tiče procjene studenata o mogućnostima implementacije obrazovanja za održivi razvoj, provedbom t-testa za nezavisne uzorke napravljena je usporedba rezultata o stavovima studenata u odnosu na istraživanje provedeno 2010., kako bi se utvrdilo postoji li statistički značajna razlika (Tablica 8 ) te je utvrđeno da od devet $^{9}$ navedenih varijabli,

9 Za istraživanje provedeno 2016. u ovu skupinu tvrdnji dodana je: "U programe studija ne bi trebalo uključivati sadržaje održivog razvoja jer je njihova primarna zadaća priprema studenata za rad u struci”, koja nije bila prisutna u istraživanju provedenom 2010. godine te u ovu usporedbu nije uključena. 
statistički značajna razlika postoji samo u tri varijable. Pritom, iako je viša razina slaganja u tri varijable u istraživanju iz 2010. u odnosu na ono iz 2016., razlike su ipak nominalno male, stoga se ne može govoriti o realnom efektu nezavisne varijable.

\subsection{Odgovornost za sustavno promicanje i provedbu obrazovanja za održivi razvoj}

Deskriptivnom razinom analize podataka u odnosu na skupinu prosudbi stavova studenata u vezi s odgovornosti za sustavno promicanje i provedbu obrazovanja za održivi razvoj (Tablica 9), dobiveni su vidljivi uvidi, prema kojima studenti najviše smatraju odgovornim Ministarstvo (44,4\%), Vladu (36,6\%) te medije (36\%). Najmanje odgovornim smatraju Sabor $(23,9 \%)$, zatim sebe $(27,4 \%)$ te političke stranke $(16,0 \%)$ za sustavno promicanje i provedbu obrazovanja za održivi razvoj.

Za promicanje i implementaciju obrazovanja za održivi razvoj postoje različiti dionici koji su odgovorni za provedbu koncepta održivog razvoja i obrazovanja za održivi razvoj. Poražavajući je rezultat da osim što studenti pripisuju nisku razinu odgovornosti institucijama obrazovanja, pripisuju je i vlastitoj odgovornosti koja se nalazi na predzadnjem mjestu. Područje obrazovanja za održivi razvoj još se uvijek smatra marginalnim te izostaje primjeren odnos prema empirijskim istraživanjima u tom području (Anđić i Tatalović Vorkapić, 2015).

Tablica 9. Postoci (\%) $i$ aritmetičke sredine (M) i standardne devijacije (SD) varijabli u vezi sodgovornosti za sustavno promicanje i provedbu obrazovanja za održivi razvoj

\begin{tabular}{|l|c|c|c|c|c|c|c|}
\hline \multirow{2}{*}{ Institucija (dionik) } & \multicolumn{5}{|c|}{ Stupanj odgovornosti } & \multirow{2}{*}{ M } & \multirow{2}{*}{ SD } \\
\cline { 2 - 7 } & $\mathbf{1}$ & $\mathbf{2}$ & $\mathbf{3}$ & $\mathbf{4}$ & $\mathbf{5}$ & & \\
\hline Ministarstva & 2,5 & 4,3 & 14,8 & 33,9 & 44,4 & 4,13 & 0,989 \\
\hline Vlada & 4,5 & 6,8 & 18,5 & 33,6 & 36,6 & 3,91 & 1,104 \\
\hline Mediji & 4,3 & 8,3 & 21,5 & 29,8 & 36,0 & 3,85 & 1,128 \\
\hline Lokalna i regionalna samouprava & 3,1 & 5,9 & 23,9 & 38,6 & 28,4 & 3,84 & 1,007 \\
\hline Škole & 3,2 & 8,6 & 24,0 & 35,4 & 28,7 & 3,78 & 1,056 \\
\hline Gospodarstvenici / gospodarstvo & 3,8 & 9,9 & 22,6 & 35,4 & 28,3 & 3,75 & 1,089 \\
\hline Udruge & 3,5 & 9,9 & 28,2 & 33,3 & 25,0 & 3,66 & 1,065 \\
\hline Visoko školstvo & 4,0 & 10,8 & 27,2 & 34,1 & 24,0 & 3,63 & 1,080 \\
\hline Sabor & 8,1 & 11,9 & 28,7 & 27,5 & 23,9 & 3,47 & 1,204 \\
\hline Vi osobno & 10,6 & 12,0 & 26,4 & 23,6 & 27,4 & 3,45 & 1,294 \\
\hline Političke stranke & 10,4 & 16,5 & 31,9 & 25,2 & 16,0 & 3,20 & 1,199 \\
\hline
\end{tabular}

* Skala procjene stupnja odgovornosti: 1-najmanja odgovornost, 5-najveća odgovornost 
Upravo je pretpostavka implementacije održivog razvoja, povećanje osviještenosti i znanja o načinima njegove praktične realizacije i paradigme u svakodnevnom životu (Rončević i sur., 2008). Stoga, obrazovanje za održivi razvoj predstavlja obrazovanje za odgovorno djelovanje i odgovorno ponašanje koje obuhvaća smisleni odnos između osobne slobode i osobne odgovornosti, promiče obrazovanje za odgovornost učenika prema samome sebi, prema drugima i prema svemu što ga okružuje (Sablić i Blažević, 2015). U odnosu na ove prosudbe statistički značajna razlika nije pronađena samo za jednu varijablu (od 11), kod usporedbe rezultata istraživanja iz 2010. i 2016.: nema razlike u prosudbi odgovornosti za sustavno promicanje provedbe obrazovanja za održivi razvoj koja se odnosi na odgovornost visokog školstva. Prema ostalim ispitivanim varijablama, usporedba rezultata istraživanja iz 2016. u odnosu na 2010. na gotovo svim tvrdnjama pokazala je u prosjeku percepciju veće odgovornost svih aktera za sustavno promicanje i provedbu obrazovanja za održivi razvoj, što je pozitivan nalaz i dozvoljava zaključivanje da studenti češće prepoznaju da cijelo društvo treba poticati implementaciju obrazovanja za održivi razvoj.

Tablica 10. Rezultati 2010. u odnosu na 2016. u procjeni odgovornosti za sustavno promicanje i provedbu obrazovanja za održivi razvoj

\begin{tabular}{|c|c|c|c|c|c|c|c|}
\hline Institucija (dionik) & Godina & $\mathbf{M}$ & SD & $\mathbf{t}$ & df & $\mathbf{p}$ & $\begin{array}{l}\text { Razlika među } \\
\text { godinama }\end{array}$ \\
\hline \multirow{2}{*}{ Vlada } & 2010. & 3,62 & 1,224 & \multirow{2}{*}{$-5,995$} & \multirow{2}{*}{2007} & \multirow{2}{*}{0,000} & \multirow{2}{*}{$2010 .<2016$} \\
\hline & 2016. & 3,91 & 1,104 & & & & \\
\hline \multirow{2}{*}{ Ministarstva } & 2010. & 3,84 & 1,110 & \multirow{2}{*}{$-6,693$} & \multirow{2}{*}{1989} & \multirow{2}{*}{0,000} & \multirow{2}{*}{$2010 .<2016$} \\
\hline & 2016. & 4,13 & 0,989 & & & & \\
\hline \multirow{2}{*}{ Sabor } & 2010. & 3,18 & 1,257 & \multirow{2}{*}{$-5,693$} & \multirow{2}{*}{2069} & \multirow{2}{*}{0,000} & \multirow{2}{*}{$2010 .<2016$} \\
\hline & 2016. & 3,47 & 1,204 & & & & \\
\hline \multirow{2}{*}{ Političke stranke } & 2010. & 2,90 & 1,193 & \multirow{2}{*}{$-6,017$} & \multirow{2}{*}{2314} & \multirow{2}{*}{0,000} & \multirow{2}{*}{$2010 .<2016$} \\
\hline & 2016. & 3,20 & 1,199 & & & & \\
\hline \multirow{2}{*}{$\begin{array}{l}\text { Lokalna i regionalna } \\
\text { samouprava }\end{array}$} & 2010. & 3,52 & 1,088 & \multirow{2}{*}{$-7,129$} & \multirow{2}{*}{2013} & \multirow{2}{*}{0,000} & \multirow{2}{*}{$2010 .<2016$} \\
\hline & 2016. & 3,84 & 1,007 & & & & \\
\hline \multirow{2}{*}{$\begin{array}{l}\text { Gospodarstvenici / } \\
\text { gospodarstvo }\end{array}$} & 2010. & 3,36 & 1,149 & \multirow{2}{*}{$-8,266$} & \multirow{2}{*}{2055} & \multirow{2}{*}{0,000} & \multirow{2}{*}{$2010 .<2016$} \\
\hline & 2016. & 3,75 & 1,089 & & & & \\
\hline \multirow{2}{*}{ Mediji } & 2010. & 3,58 & 1,180 & \multirow{2}{*}{$-5,616$} & \multirow{2}{*}{2072} & \multirow{2}{*}{0,000} & \multirow{2}{*}{$2010 .<2016$} \\
\hline & 2016. & 3,85 & 1,128 & & & & \\
\hline Udruge & 2010. & 3,46 & 1,144 & -4332 & 2031 & 0000 & $2010<2016$ \\
\hline Garuge & 2016. & 3,66 & 1,065 & (2) - & 2031 & 0,000 & $2010 .<2010$ \\
\hline Škole & 2010. & 3,65 & 1,105 & -2761 & 2080 & 0006 & $2010<2016$ \\
\hline SKUIC & 2016. & 3,78 & 1,056 & $-2, / 01$ & 2080 & 0,000 & $2010 .<2010$ \\
\hline Vi osobno & 2010. & 3,15 & 1,344 & 25 & 2322 & 0,000 & 2 \\
\hline & 2016. & 3,45 & 1,294 & & & 0,000 & 2010.02010 \\
\hline
\end{tabular}




\section{ZAKLJUČNA RAZMATRANJA}

Primjena koncepta održivog razvoja u svakodnevni život dugotrajan je i složen proces. Da bi se ostvarila održiva budućnost, odnosno održivo življenje (Lay, 2017), neophodno je neprekidno jačanje svijesti o potrebi prihvaćanja koncepta održivog razvoja te razvijanja obrazovne perspektive koja promiče ovaj koncept, odnosno, prije svega, omogućuje njegovo razumijevanje. $U$ tom je smislu u ovom istraživanju od posebnog značaja bilo ispitati stavove studenata o mogućnostima implementacije obrazovanja za održivi razvoj u studijske programe te ustanoviti je li došlo do promjena u stavovima u razdoblju između 2010. i 2016? Dobiveni rezultati upućuju na to da studenti smatraju teme održivosti važnima za njihovu struku i zanimanje te ističu potrebu njihove integracije u programe studija, što predstavlja poseban izazov za sveučilišne nastavnike. Međutim, najviše odgovornosti za promicanje i provedbu obrazovanja za održivi razvoj studenti pripisuju Ministarstvu, zatim Vladi i medijima te na neki način pokazuju i nerazumijevanje autonomnosti sveučilišta u kreiranju studijskih programa i značaja motiviranosti nastavnika za razvijanjem slaba u kojima će biti uključene teme o održivosti i održivom razvoju.

Što se tiče zainteresiranosti u odnosu na preferencije prema uključivanju pojedinih tema o održivosti i održivom razvoju u studijske programe, kao i s obzirom na varijablu razine studija koje ispitani studenti pohađaju, ne pronalaze se razlike između rezultata istraživanja provedenih 2010. i 2016.

Nadalje, nešto je manje od polovice studenata $(45,3 \%)$ tijekom studija slušalo neki kolegij u kojem su se obrađivale teme održivog razvoja / održivosti. I studenti iz 2010. i oni iz 2016. navode slične kolegije, odnosno teme kroz koje je obuhvaćen održivi razvoj. Dio studenata ističe da ne raspolaže dovoljnim znanjem o održivom razvoju, a dio smatra da je teme održivosti potrebno implementirati u ranijem obrazovanju. Kao prepreku implementaciji studenti navode opsežnost studijskih programa koji su preopterećeni i bez tema o održivosti.

S obzirom na ispitivanje stavova studenata o (ne)zainteresiranosti za uključivanje područja održivosti u studijski program, studenti iz 2010. i 2016. iskazali su najveći interes za uključivanjem područja: siromaštvo i razvoj $(62,7 \%)$, ravnopravnost spolova $(59,2 \%)$, kvaliteta vode i zraka $(57,7 \%)$, čim se na određeni način pokrivaju temeljne teme održivog razvoja, dok je najmanji interes za: pomorstvo i promet u funkciji održivog razvoja $(26,6 \%)$, bioekonomiju, biomaterijale, biorafiniranje $(30,2 \%)$ te bioetiku $(30,3 \%)$.

U odnosu na zainteresiranost studenata za određene razine studija iz područja održivog razvoja, najviši postotak odnosi se na preddiplomski studij (16,5\%), a najmanji na stručni studij $(7,2 \%)$. Značajan nalaz istraživanja odnosi se i na to da studenti 2010. iskazuju veću zainteresiranost za sve razine studija od ispitanih studenata 2016. Iako se održivi razvoj često spominje u različitim područjima života, taj se kontekst u praksi još uvijek slabo razumije i provodi.

Prema navedenoj interpretaciji rezultata, vidljivo je da postoji interes studenata za implementacijom odgoja i obrazovanja za održivi razvoj u sveučilišne djelatnosti, ali da 
pred samom implementacijom ipak postoje određene prepreke. Interes studenata bi zasigurno bio veći kada bi studenti bili bolje informirani o problemu održivosti. Stoga je jasno da je neophodna edukacija samih studenata i drugih aktera odgojno-obrazovnih djelatnosti o održivom razvoju. Jedna od prepreka je i opsežnost programa koji sugerira da su potrebne i promjene u kurikulumu. U kurikulum je potrebno ugraditi teme vezane uz koncept održivog razvoja u postojeće predmete, pokrenuti nove planove i programe koji će kod studenata razvijati znanja, vještine, kompetencije i vrijednosti, a pridonosit će održivom razvoju, pokrenuti posebne predmete koji se bave područjima održivog razvoja te razvijati ostale aktivnosti koje kod studenata potiču stvaranje svijesti o potrebama održivog razvoja (Črnjar, 2015:161).

Rezultati istraživanja generalno ukazuju na zaključak kako i nove generacije imaju stavove slične prethodnima, dakle nema naznaka ni pozitivnog ni negativnog pomaka. Indikativno je to što je, primjerice, u svojoj prethodnoj Strategiji razvoja Sveučilište u Rijeci za razdoblje 2007.-2013., naglasilo svoju zadaću u promicanju načela održivog razvoja i osjetljivosti za očuvanje okoliša, uvažavajući Sveučilišnu povelju za održivi razvoj (The University Charter for Sustainable Development, 1994), kao i Strategiju obrazovanja za održivi razvoj UNECE (The United Nations Economic Commission for Europe) i Geteboršku strategiju održivog razvoja (Lučin, 2007:69) kojima je odgoj i obrazovanje za održivi razvoj postavljen zajedan od ciljeva. Ipak, u aktualnoj se Strategiji, za razdoblje od 2014. do 2020. (Sušanj, 2014) održivi razvoj marginalno spominje.

Osim promjena koje su nužne u visokom školstvu, potrebne su promjene i na nižim razinama obrazovanja. Obrazovanje za održivi razvoj nije jednokratno učenje, nego potreba za cjeloživotnim učenjem i osposobljavanjem ljudi da žive i djeluju na način koji pridonosi održivom razvoju. $U$ tom se smislu sve više javlja potreba za implementacijom obrazovanja za održivi razvoj u sveučilišne djelatnosti te za pokretanjem novih planova i programa. Također, nameće se i potreba za međunarodnom suradnjom institucija te razmjenom profesora i studenata koja je ključna za razmjenu ideja i stvaranje mreža znanja i eksperata (Črnjar, 2015:162). U ovom radu bavile smo se većinom stavovima prema obrazovanju za održivi razvoj te temama održivog razvoja, međutim obrazovne institucije trebaju implementirati sadržaje održivog razvoja u širem smislu, kako bi osposobile učenike i studente $s$ vrijednostima, znanjima i vještinama za održivo življenje u zajednici. Obrazovanje za održivi razvoj zahtijeva i partnerstvo između zainteresiranih strana, vlade i lokalnih vlasti, medija te nevladinih udruga, odnosno lokalno obrazovanje (engl. place based education), u okviru kojeg učenje uvažava osobna iskustva učenika i studenata (Smith, 2002:586). Drugim riječima, očekuje se da oni koji kreiraju obrazovne politike kao i nastavnici krenu s transformacijom nastavnih programa, u pravcu osvjetljavanja kompetencija koje se bave složenošću današnjeg svijeta (Stokols, 2017:199). 


\section{LITERATURA}

Anđić D. i Tatalović Vorkapić, S. (2015). Kako mjeriti održivo ponašanje? Adaptacija i validacija Upitnika o održivom ponašanju. Revija za sociologiju, 45(1): 69-97.

Anđić, D. i Tatalović Vorkapić, S. (2017). Teacher education for sustainability: The awareness and responsibility for sustainability problems. Journal od teacher education for sustainability, 19(2): 121-137.

Bervar, M. i Bertoncelj, A. (2016). The Five Pillars of Sustainability: Economic, Social, Environmental, Cultural and Security Aspects. U: Laporšek, S. i Gomezelj Omerze, D. (ur.), Management International Conference 2016: Managing Global Changes (str. 243-244). Koper: University of Primorska Press.

Cifrić, I. (2012). Leksikon socijalne ekologije. Zagreb: Školska knjiga

Cifrić, I. (2009). Kultura i okoliš. Zaprešić: Visoka škola za poslovanje i upravljanje „Baltazar Adam Krčelić“.

Črnjar, K. (2015). Doprinos visokoga obrazovanja razvoju i implementaciji obrazovanja za održivi razvoj. U: Črnjar, M. (ur.), Zbornik radova. Prostorno planiranje kao čimbenik razvoja u županijama (str. 155-164). Rijeka: Javna ustanova Zavod za prostorno uređenje Primorsko-goranske županije.

D’Alisa, G., Demaria, F. i Kallis, G. (ur.) (2016). Odrast: Pojmovnik za novu eru. Zagreb: Fraktura i Institut za političku ekologiju.

Devernay, B., Garašić, D. i Vučić, V. (2001). Odgoj i obrazovanje za okoliš i održivi razvoj: priručnik za nastavnike i odgajatelje. Zagreb: Društvo za unapređivanje odgoja i obrazovanja.

Domazet, M. i Dolenec, D. (2016). Odrast kao obnova utopijskih energija, Predgovor hrvatskom izdanju. U: D’Alisa, G., Demaria, F. i Kallis, G. (ur.), Odrast: Pojmovnik za novu eru (str. XI-XXVII). Zagreb: Fraktura i Institut za političku ekologiju.

Drljača, M. (2012). Koncept održivog razvoja i sustav upravljanja. Međunarodni skup Nedelja kvaliteta, Kvalitet i izvrsnost, 1(1-2): 20-26; 110. Beograd: FQCE - Fondacija za kulturu kvaliteta i izvrsnost.

Fudge, J. (2015). Migration and Sustainable Development in the EU: A Case Study of the Seasonal Workers Directive. International Journal of Comparative Labour Law and Industrial Relations, 31(3): 331-349.

Hackl, A. (2018). Mobility equity in a globalized world. Reducing in equalities in the sustainable development agenda. World Development, 112: 150-162.

Kemp, R. i Parto, S. (2005). Governance for sustainable development: moving from theory to practice, International Journal for Sustainable Development, 8(1-2): 12-30.

Konferencija Ujedinjenih naroda o okolišu i razvoju - UNCED (1992). Agenda 21. Rio de Janeiro, Brazil, 3.-14. lipnja 1992. URL: https://sustainabledevelopment.un.org/ content/documents/Agenda21.pdf (08.05.2019.)

Kostović-Vranješ, V. (2016). Inicijalno obrazovanje i profesionalno usavršavanje učitelja usmjereno prema osposobljavanju za promicanje obrazovanja za održivi razvoj. Zbornik radova Filozofskog fakulteta u Splitu, 6-7: 166-168. 
Lay, V. (1992). Održivi razvitak i društvene promjene, prilozi rekonceptualizaciji današnjeg tipa razvitka. Socijalna ekologija, 1(1): 1-18.

Lay, V. (1994). Primijenjeno obrazovanje za okoliš. Elementi modela za potrebe regija u Hrvatskoj. Socijalna ekologija, 3(3-4): 289-300.

Lay, V. (2017). Ja i moje, vaše, naše, sutra: Kako danas artikulirati odgoj i obrazovanje za održivost i održivo življenje? U: Radeka, I. (ur.), Održivi razvoj i odgojno-obrazovni sustav Hrvatske (str. 17-26). Zadar: Sveučilište u Zadru i Dječji vrtić "Radost".

Lay, V. i Puđak, J. (2008). Sociološke dimenzije odgoja i obrazovanja za održivi razvoj. U: Uzelac, V. i Vujičić, L. (ur.), Cjeloživotno učenje za održivi razvoj (str. 95-105). Rijeka: Sveučilište u Rijeci, Učiteljski fakultet.

La Vina, A. G. M., Hoff, G. i DeRose A. M. (2003). The Outcomes of Johannesburg: Assessing the World Summit on Sustainable Development. SAIS Review: A Journal of International Affairs, 23(1): 53-70.

Lučin, P. (ur). (2007). Strategija razvoja Sveučilišta u Rijeci 2007-2013. Rijeka: Sveučilište u Rijeci.

McMillan, E. E., Wright, T. i Beazley, K. (2004). Impact of a University-Level Environmental Studies Class on Students' Values. The Journal of Environmental Education, 35(3): 19-28.

Opća skupština Ujedinjenih naroda (1997). Earth Summit + 5. Special Sessionof the General Assembly to Review and Appraise the Implementation of Agenda 21. New York, 23.- 27. lipnja 1997. URL: https://www.un.org/esa/earthsummit/ga97rep. htm (08.05.2019.)

Opća skupština Ujedinjenih naroda (2012). Future we want. Rezolucija Opće skupštine Ujedinjenih naroda, A/RES/66/288, 11. rujna 2012. URL: https://www.un.org/ga/ search/view_doc.asp?symbol=A/RES/66/288\&Lang=E (09.05.2019.)

Opća skupština Ujedinjenih naroda (2015). Transforming our world: the 2030 Agenda for Sustainable Development. Rezolucija Opće skupštine Ujedinjenih naroda, A/ RES/70/1, 21. listopada 2015. URL: https://www.un.org/ga/search/view_doc. asp?symbol=A/RES/70/1\&Lang=E (05.11.2019.)

Palmer, A. J. (1998). Environmental Education in the 21st Century. Theory, practice and promise. London: Routledge.

Rakić, V. i Vukušić, S. (2010). Odgoj i obrazovanje za vrijednosti. Društvena istraživanja: časopis za opće društvena pitanja, 19(4-5): 771-795.

Rončević, N., Ledić, J. i Ćulum, B. (2008). „Nisam sigurna što je, ali je bitno“-analiza stavova studenata Sveučilišta u Rijeci o održivom razvoju. Contemporary Issues, 1(1): $62-75$.

Rončevič, N. i Rafajac, B. (2012).Održivi razvoj - izazov za sveučiliste?? Rijeka: Filozofski fakultet Sveučilišta u Rijeci.

Sablić, M. i Blažević, I. (2015). Stavovi učitelja prema vrijednostima kao temeljnim sastavnicama Nacionalnog okvirnog kurikuluma. Školski vjesnik, 64(2): 251-265.

Sachs, D. J. (2015). The Age of Sustainable Development. New York: Columbia University Press. 
Shepard, K. (2015). Higher Education for Sustainable Development. London: Palgrave Macmillan.

Smith, G. A. (2002). Place-based education: Learning to be where we are. Phi Delta Kappan, 83(8): 584-594.

Sterling S. (2004). An Analysis of the Development of Sustainability Education Internationally: Evolution, Interpretation and Transformative Potential U: Blewitt J. i Cullingford C. (ur.), The Sustainability Curriculum: The Challenge for Higher Education (str. 43-63). London: Earthscan Ltd.

Stokols, D. (2017). Social Ecology in the Digital Age. Solving Complex Problems in Globalized World. London: Academic Press.

Sušanj, Z. (ur.) (2014). Strategija razvoja Sveučilišta u Rijeci 2014.-2020. Rijeka: Sveučilište u Rijeci.

Ujedinjeni gradovi i lokalne uprave - UCLG (2004). Agenda 21 for Culture. Barcelona: United Citiesand Local Governments (UCLG) and Ajuntament de Barcelona: Institut de Cultura. URL: http://www.agenda21culture.net/sites/default/files/files/ documents/multi/ag21_en.pdf (08.05.2019.)

World Commission on Environment and Development - WCED (1987). Our Common Future. Oxford, NY: Oxford University Press. 


\title{
TOWARD THE POSSIBILITY OF IMPLEMENTATION OF EDUCATION FOR SUSTAINABLE DEVELOPMENT AT THE UNIVERSITY LEVEL
}

\author{
Ivanka Buzov, Elena Cvitković and Nena Rončević
}

\begin{abstract}
The theoretical part of the paper explores the concept of sustainable development, the importance of education for sustainable development, which can contribute to a sustainable future, the responsibility for the systematic promotion and implementation of education for sustainable development, and the need to implement sustainability topics in study programs. The empirical part of the paper presents the results of a study conducted in 2016 on a representative sample of students at the University of Rijeka $(N=1347)$, which are then compared with a similar study conducted in 2010 ( $N=1001)$. It examines students' attitudes toward some dimensions of education for sustainable development and their interest in different topics of sustainable development, as well as their interest in study programs to be focused on these topics and concept. It also analyses their perception of the possibilities and ways of implementing sustainable development issues into study programs, and of the responsibility for a systematic promotion and implementation of sustainable development education. A comparison between the 2010 and 2016 surveys concludes that students cite similar courses and topics that cover sustainable development. However, in 2016 sample they show less interest in all levels of study offered in the field of sustainable development. Furthermore, some students point out that they do not have sufficient knowledge on sustainable development, and some believe that sustainability topics need to be implemented at earlier levels of education. With regard to expressed interest in sustainability topics in study programs, they mostly emphasize the need to include those related to human rights, food security, poverty and development, gender equality, and water and air quality. Finally, students exhibit a misunderstanding of the university's autonomy in creating study programs and attribute responsibility for promoting and implementing education for sustainable development to Ministry, Government and the media.
\end{abstract}

Key words: education for sustainable development, training for sustainable development, responsibility, sustainability, students' attitudes

\section{MÄGLICHKEITEN DER IMPLEMENTIERUNG DER BILDUNG ZURNACHHALTIGEN ENTWICKLUNG AN DER UNIVERSITÄT}

\author{
Ivanka Buzov, Elena Cvitković und Nena Rončević
}

\begin{abstract}
Zusammenfassung
Im theoretischen Teil der Arbeit werden das Konzept der nachhaltigen Entwicklung, die Wichtigkeit der Bildung zur nachhaltigen Entwicklung, mit der die nachhaltige Zukunft verwirklicht werden kann, die Verantwortung für systematische Förderung und Durchführung der Bildung zur nachhaltigen Entwicklung, sowie die Notwendigkeit der Implementierung des Themas der Nachhaltigkeit in die Studienprogramme kurz erklärt. Im empirischen Teil der Arbeit werden die Ergebnisse der im Jahre 2016 durchgeführten Forschung an der Universität in Rijeka $(N=1347)$ präsentiert, die dann mit den Ergebnissen der im Jahre 2010 durchgeführten Forschung (N=1001) verglichen werden. Von Befragung der Studenten zu einigen Dimensionen der Bildung zur nachhaltigen Entwicklung wird dann deren Interesse an verschiedenen Themen und damit verbundenen Studienprogrammen der nach haltigen Entwicklung analysiert, dann die Wahrnehmung der Möglichkeiten und Arten der Implementierung der Problematik der nachhaltigen Entwicklung in die Studienprogramme und schließlich die Wahrnehmung der Verantwortung für eine systematische Förderung und Durchführung der Bildung zur nachhaltigen Entwicklung. Aus dem Vergleich
\end{abstract}


beider Forschungen aus den Jahren 2010 und 2016 kann man den Schlußziehen, dass ähnliche Kollegs und Themen angeführt werden, und dass Studenten aus dem Muster aus 2016 weniger Interesse an allen angebotenen Ebenen des Studiums aus dem Bereich der nachhaltigen Entwicklung zeigen. Weiterhin hebt ein Teil der Studenten hervor, dass sie nicht über genug Wissen über die nachhaltige Entwicklung verfügen und ein Teil von ihnen findet, dass man das Thema der Nachhaltigkeit in frühere Ebenen der Bildung implementieren sollte. Was ihr Interesse am Thema der Nachhaltigkeit betrifft, heben sie größtenteils die Notwendigkeit hervor, die Themen in die Studienprogramme einzuschließen, die sich auf Menschenrechte, Nahrungssicherheit, Armut und Entwicklung, Gleichberechtigung der Geschlechter und die Qualität von Luft und Wasser beziehen. Studenten weisen ein Unverständnis der Autonomie der Universität bei der Verfassung von Studienprogrammen und der Verantwortung für Förderung und Durchführung der Bildung für nachhaltige Entwicklung auf, indem sie die Verantwortung für Förderung und Durchführung der Bildung als eine Aufgabe der Ministerien, der Regierung und der Medien sehen.

Schlüsselwörter: Erziehung und Bildung für nachhaltige Entwicklung, Verantwortung, Nachhaltigkeitsbereiche, Stellungnahmen von Studenten 